\title{
Penalaran Matematika: Apa Aspek Sentralnya?
}

\author{
Rosida Marasabessy ${ }^{1}$, Aan Hasanah ${ }^{2}$ \\ 1, 2 Program Studi Pendidikan Matematika, FPMIPA, Universitas Pendidikan Indonesia, \\ Jl. Setiabudi No 229, Bandung, Indonesia \\ rosidamarasabessy@upi.edu
}

\begin{abstract}
The development of students' mathematical reasoning is the goal of the Indonesian education curriculum and several abroad. But what mathematical reasoning consists of is not always clear. In general, everyone has his or her own understanding of mathematical reasoning. The method used in this article is a literature review. This article aims to clarify mathematical reasoning aspects from a theoretical perspective by elaborating articles on mathematical reasoning to contribute to further research. To achieve this elaboration, a literature search has been carried out with the keywords mathematical reasoning, mathematical thinking, deductive reasoning, inductive reasoning, etc. The synthesis carried out leads to mathematical reasoning aspects from the analysis of the mathematics education research literature on mathematical reasoning. The steps in conducting a literature review are: first, choosing articles with mathematical reasoning keywords and other keywords related to reasoning. Second, the literature analysis is carried out. Third, perform a synthesis to highlight convergence, divergence, and pinpoint areas where there are theoretical gaps that need to be filled by any model representing the central aspects of reasoning. At the end of the process, 25 articles in English and Indonesian constitute literature. The aspects described here consist of two main aspects: structural aspects and process aspects, both of which are necessary to capture the central characteristics of mathematical reasoning. The structural aspect of reasoning consists of the deductive step, the inductive step, and the abductive step. Meanwhile, aspects of the mathematical reasoning process consist of processes related to finding similarities and differences and validation processes.
\end{abstract}

Keywords: Mathematical Reasoning, Structural Aspects of Mathematical Reasoning, Process Aspects of Mathematical Reasoning

\begin{abstract}
Abstrak
Pengembangan penalaran matematis siswa merupakan tujuan dari kurikulum pendidikan Indonesia dan beberapa kurikulum diluar negeri. Tapi terdiri dari apa penalaran matematika tidak selalu jelas, secara umum setiap orang memiliki pengertian tentang penalaran matematikanya sendiri. Metode yang digunakan dalam artikel ini adalah literature review. Artikel ini bertujuan untuk memperjelas aspek-aspek penalaran matematika dari perspektif teoritis, dengan mengelaborasi artikel-artikel penalaran matematika sehingga berkontribusi pada penelitian selanjutnya. Untuk mencapai elaborasi tersebut, dilakukan pencarian literatur dengan kata kunci penalaran matematika, pemikiran matematis, penalaran deduktif, penalaran induktif dan sebagainya. Dari analisis literatur penelitian pendidikan matematika tentang penalaran matematika, sintesis yang dilakukan mengarah pada aspek penalaran matematika. Langkah literature review adalah: pertama, memilih artikel dengan kata kunci penalaran matematika dan kata kunci lain yang terkait dengan penalaran. Kedua, dilakukan penganalisaan literatur. Ketiga, melakukan sintesis untuk menyoroti konvergensi, divergensi, dan untuk menunjukkan area di mana terdapat kesenjangan teoritis yang perlu diisi oleh model apapun yang dapat mewakili aspek sentrak penalaran. Pada akhir proses dilakukan analisis 25 artikel Aspek yang diuraikan disini, terdiri dari dua aspek utama: aspek struktural dan aspek proses, yang keduanya diperlukan untuk menangkap karakterisitik sentral dari penalaran matematika. Aspek struktur dari penalaran terdiri dari langkah deduktif, langkah induktif dan langkah abduktif. Sedangkan, aspek proses penalaran matematis terdiri dari proses yang berhubungan dengan pencarian persamaan dan perbedaan dan proses yang terkait dengan validasi.
\end{abstract}

Kata kunci: penalaran matematika, aspek struktural penalaran matematika, aspek proses penalaran matematika.

Copyright (c) 2021 Rosida Marasabessy, Aan Hasanah

$\triangle$ Corresponding author: Rosida Marasabessy

Email Address: rosidamarasabessy@upi.edu (Jl. Setiabudi No 229, Bandung, Indonesia)

Received 09 Desember 2020, Accepted 03 Maret 2021, Published 17 Maret 2021

\section{PENDAHULUAN}

Apa itu penalaran matematika? Bagaimana kita bisa menggambarnya? Pertanyaan-pertanyaan inilah yang mendasari pengembangan aspek penalaran matematis yang menjadi fokus artikel ini. Dokumen kurikulum di seluruh dunia menekankan pembinaan penalaran matematika siswa sebagai 
tujuan penting (NCTM, 2000; OCDE, 2006), cara penalaran matematika dijelaskan dalam dokumen tersebut cenderung tidak jelas, tidak sistematis, dan bahkan kontradiktif dari satu dokumen ke dokumen lainnya (Jeannotte \& Kieran, 2017). Demikian pula, dalam komunitas riset pendidikan matematika, wacana tentang penalaran matematika tidak monolitik yang bertarti tidak terdiri dari satu suara. Berbagai visi matematika, pembelajaran dan pengajaran saling bergandengan. Faktor tambahan menambah kebingungan, seperti yang ditunjukkan oleh Yackel \& Hanna (2003): "Menulis tentang penalaran matematika dipersulit oleh fakta dari istilah penalaran seperti pemahaman, banyak digunakan dengan asumsi implisit bahwa ada kesepakatan universal tentang artinya”.

Fakta menunjukkan banyak matematikawan dan pakar pendidikan matematika menggunakan istilah penalaran matematika tanpa klasifikasi atau elaborasi (Yackel \& Hanna, 2003). Lithner (2006), menjelaskan fungsinya untuk menghasilkan pengetahuan baru; dan Duval (1995) menjelaskan fungsinya untuk mengubah nilai epistemik dari proposisi tertentu. Definisi dari bentuk klasik penalaran matematika, seperti deduktif, induktif dan abduktif, semuanya dapat ditemukan tetapi dengan berbagai penekanan. Duval (1995), menegaskan hanya penalaran deduktif yang dapat dianggap matematis. Sedangkan, Reid (2003), Rivera (2008), dan Meyer (2010) menunjukkan pentingnya penalaran abduktif dalam penemuan matematika. Berbeda dengan aspek struktural terkait dengan bentuk penalaran matematika, hasil sintesis juga mengungkapkan karakteristik dari penalaran matematika menekankan proses yang mendasarinya. Proses dari penalaran matematika adalah conjecturing atau dugaan (Mason et al., 2010); generalizing atau generalisasi (Stylianides, 2008), exemplifying atau mencotohkan (Mason et al., 2010), dan proving atau membuktikan (Duval, 1995).

Beberapa sorotan dari literatur penelitian tentang penalaran matematika menunjukkan belum ada yang mengkaji secara konseptual mengenai penalaran matematika. Banyak dari litertur menjelaskan penggunaan model dan pendekaran untuk meningkatkan kemampuan penalaran matematika siswa (Bernard \& Chotimah, 2018). Keadaan di lapangan saat ini mempersulit untuk membandingkan pendekatan dan karakteristik dari penalaran matematika, selain itu hasil studi terkait. Pentingnya mengembangkan penalaran matematika dalam proses belajar mengajar di berbagai tingkat sekolah, serta kebutuhan akan sumber daya konseptual substantif tentang penalaran matematika dalam pelatihan dan pengembangan profesional guru, juga berfungsi untuk memotivasi guru untuk memiliki wawasan mendalam mengenai penalaran matematika.

Dengan demikian, tujuan dari penelitian ini adalah untuk menguraikan secara teoritis dua aspek utama dari penalaran matematika, yang keduanya diperlukan untuk menangkap karakteristik sentral dari penalaran matematika. Penjelasan selanjutnya adalah pendirian epistemologis yang merupakan inti dari keseluruhan proses, sejalan dengan kerangka teoritis yang diadopsi, yang pada gilirannya memainkan peran sebagai lensa interpretatif untuk menggambarkan fitur-fitur utama penalaran matematis. Dari hasil studi literatur, berikut presentasi dari kajian teoritis. Asumsi sosial Kultural dan kognitif menjadi kajian teori dalam penelitian ini. Perubahan sosial kultural dalam penelitian pendidikan matematika telah membuat masyarakat peka tidak hanya pada fenomena kemunculan 
budaya matematika di kelas oleh pesertanya (baik guru dan peserta didik), tetapi juga peran yang dimainkan oleh cara-cara penalaran dan komunikasi yang mengacu pada praktik-praktik dari disiplin ilmu (Grouws, 2006).

Cara-cara penalaran matematis ini juga direfleksikan dalam literatur didaktik tentang penalaran matematika di setiap tingkatan pendidikan. Kegiatan penalaran siswa terdiri dari apa yang siswa katakan, cara mereka mengatakannya, apa yang mereka lakukan, representasi dan gambar yang mereka buat, cara mereka menggunakan representasi ini, dan intonasi serta gerak tubuh mereka, semua ini adalah batu pijakan untuk guru sehubungan dengan pembudayaan siswa dengan cara berpartisipasi dan cara bernalar yang diharapkan dari mereka. Untuk memberikan masukkan ini, guru tidak hanya harus menyadari sifat, bentuk dan proses penalaran matematika yang mereka inginkan agar siswa belajar untuk berpartisipasi, tetapi juga mengenali ketika terlibat dalam aspek penalaran yang diinginkan. Hal ini membutuhkan visi penalaran matematika yang dielaborasi dengan baik di mana wacana adalah hal fundamental dan yang tidak hanya mencerminkan wacana didaktis dari disiplin tetapi juga berfungsi sebagai alat konseptual bagi guru dan peneliti untuk menganalisis aktivitas penalaran siswa.

Dari pandangan sosiol kultural sebelumnya, penalararan matematika dapat dilihat sebagai aktivitas diskursif. Untuk mengkonseptualisasi penalaran matematika sebagai aktivitas diskursif, digunakan kerangka kerja kognitif yang dikembangkan oleh Sfard (2008). Sfard (2008) mendefinisikan kognitif sebagai "istilah yang meliputi berpikir (kognisi Individu) dan berkomunikasi (interpersonal)". Kombinasi dari kata-kata komunikasi dan kognisi, ini menekankan fakta bahwa kedua proses ini adalah manisfestasi yang berbeda (intrapersonal dan interpersonal) dari fenomena yang sama. Dalam kerangka kognitif, analisis wacana menjadi central. Menurut Sfard (2008), wacana adalah jenis komunikasi khusus yang dibuat dengan mengulang tindakan yang dapat diterima dan dalam bahasa wacana dapat dibedakan dengan komunikasi verbal, mediator visual, rutinitas, dan narasi yang didukung.

Bagi peneliti kognitif, matematika adalah wacana, yaitu jenis komunikasi tertentu (Sfard, 2008). Perkembangan wacana matematika yaitu perkembangan matematika melibatkan perubahan wacana yang terjadi dalam komunitas matematika di mana seseorang berkembang. Dalam gerakan individualisasi dan recommunication, perubahan tersebut diajukan, ditolak dan dinegosiasikan. Misalnya, Sfard (2008) mencatat bahwa aljabar adalah meta-wacana yang menggolongkan wacana aritmatika dan wacana itu sendiri. Dari sudut pandang epistemolog, posisi ini memiliki implikasi bahwa cara penalaran matematika akan dikonseptualisasikan. Komunitas matematika tempat seseorang berevolusi itulah yang menetapkan aturan, mediator visual yang dapat diterima, dan penggunaan kata.

Kamus Oxford mendefinisikan narasi sebagai komunikasi lisan atau tertulis dari suatu peristiwa dan representasi dari situasi atau proses tertentu sedemikian rupa mencerminkan atau menyesuaikan diri dalam serangkaian tujuan atau nilai yang menyeluruh. Peristiwa yang direpresentasikan dan diinterpretasikan melalui kerangka diskursif yang menopang penalaran matematika adalah aspek-aspek penalaran matematika yang telah menjadi bagian dari narasi terkini dalam komunitas pendidikan matematika. Dan kerena narasi mengundang interpretasi dari penalaran matematika itu sendiri, akan 
berkembang ketika orang lain dari sudut pandang lain membacanya, dan mengambil serta menyesuaikannya dengan praktik mereka sendiri.

Terdapat dua jenis pengembangan diskursif dalam pendekatan kognitif, yaitu level-objek dan meta-level. Pengembangan wacana level-objek mengacu pada perluasan wacana yang ada pada objek matematika yang sudah dikonstruksi. Di sisi lain, pengembangan wacana meta-level mengacu pada konstruksi wacana baru, mengubah aturan main yang sejalan dengan pembangunan objek matematika baru. Perbedaan antara jenis pengembangan diskursif ini akan penting dalam membedakan proses berpikir matematis yang akan dianggap sebagai proses penalaran matematika.

Elaborasi penalaran matematika untuk setiap jenjang pendidikan merupakan landasan utama penelitian ini, di mana memiliki implikasi dan batasan tertentu. Tujuan penelitian ini bukan untuk membangun sebuah konsep yang memberikan saran praktis khusus yang berhubungan dengan urutan tugas kelas yang dirancang untuk mendorong pengembangan penalaran matematis dan bukan bertujuan untuk membangun konsep yang menggambarkan cara penelitian dimana siswa mengembangkan dan mengkomunikasikan penalaran matematika tertentu. Sebaliknya, tujuannya adalah untuk membangun, dalam satu kesatuan yang selaras dengan kerangka kognitif, konsep teoritis yang koheren dalam mensintesis dan dibangun di atas konvergensi yang akan ditemukan dalam jenis dan karakteristik utama penalaran matematika yang dijelaskan dalam literatur penelitian pendidikan matematika dan dengan demikian dapat berfungsi sebagai alat untuk pengajar dan peneliti, yaitu konsep naratif yang menghubungkan konsep yang berbeda secara semantik tetapi dalam jaringan koheren yang sama.

Disini dijelaskan metodologi yang digunakan yaitu studi pustaka. Kemudian, disajikan juga gambaran dari beberapa fitur kunci penalaran matematis yang diekstraksi dari literatur, fitur yang ikut membentuk aspek sentral dari penalaran matematika untuk setiap jenjang pendidikan. Namun, harus ditekankan bahwa hasilnya bukanlah konsep unik yang menyatukan semua divergensi yang ditemukan dalam literatur. Akan tetapi, merupakan sebuah konsep yang mensistematisasikan berbagai fitur konvergen penalaran matematika dalam kerangka yang secara teoritis koheren. Seperti yang dikemukakan oleh Stylianides (2008): "tantangan ilmiah penelitian dalam pendidikan matematika adalah membentuk tubuh pengetahuan yang kokoh yang berarti valid secara teoritis dan relevan yang berarti instrumental bagi praktisi dan pemangku kepentingan lainnya serta konvergensi harus menjadi aturannya".

\section{METODE}

Proses metodologis yang digunakan dalam penelitian ini adalah literature review. Menurut Shuttleworth (2009), "Literature Review is a critical and in depth evaluation of previous research". Dari penjelasan Shuttleworth dapat kita simpulkan bahwa literature review tidak hanya bermakna membaca literatur, akan tetapi lebih ke arah evaluasi yang mendalam dan kritis tentang penelitian sebelumnya pada suatu topik. Sedangkan menurut Creswell (2003), mencari, memilih, menimbang dan membaca literatur adalah pekerjaan pertama dalam proyek penelitian apapun. Adapun langkah-langkah dalam 
melakukan literature review pada penelitian ini adalah: pertama, memilih artikel dengan kata kunci penalaran matematika dan kata kunci lain yang terkait dengan penalaran seperti penalaran deduktif, penalaran induktif, dan sebagainya. Empat kriteria untuk memilih artikel adalah akses, kelengkapan, kebaruan dan keaslian (Van der Maren, 1996). 1000 jurnal ditemukan peneliti lewat software publish or perish 7 sesuai kata kunci, kemudian sebanyak 266 jurnal dari jurnal yang ditemukan sesuai kata kunci pencarian tersebut kemudian dilakukan skrining, selanjutnya 87 jurnal full teks dilakukan asesmen kelayakan. Pada akhir proses, 25 artikel dalam bahasa Inggris dan bahasa Indonesia (buku, artikel, dan laporan penelitian dalam prosiding) merupakan literatur.

Kedua, dilakukan penganalisaan literatur yang digunakan dalam penelitian untuk informasi yang relevan terkait dengan karakteristik formal, aksiologis, dan praktis penalaran matematika. Karakteristik formal mengacu pada akurasi, deskripsi, ekspresi, dan definisi konsep, istilah, gagasan. Karakteristik aksiologis mengacu pada tujuan, sasaran, prinsip. Sedangkan, karakteristik praktis mengacu pada norma, keputusan, praktik teoritis atau eksperimental, kebiasaan, dan adat istiadat. Analisis isi dan konseptual mendukung proses pembangunan aspek-aspek penalaran matematika. Pembacaan yang berurutan dan berulang memungkinkan untuk menemukan unit penalaran matematika yang akan dikategorikan. Setiap unit menerima tiga kode: i) deskripsi yang terkait dengan sifat informasi (formal, aksiologis, atau praksis); ii) deskripsi yang terkait dengan isinya (misalnya, penalaran deduktif, penalaran abduktif, inferensi, dugaan, pembuktian, dan lain-lain); dan iii) deskripsi terkait dengan karakteristik yang muncul dari penalaran matematika (misalnya, struktur, proses). Kodefikasi ketiga ini membantu dalam pembangunan unsur-unsur dan aspek dari penalaran matematika. Misalnya, nalar adalah menyimpulkan proposisi yang disebut kesimpulan dari premis tertentu (Stylianides, 2008), yang tidak hanya memberikan informasi formal, tetapi juga ditautkan ke inferensi kata kunci, dan menyoroti keduanya sebagai aspek struktural (yaitu premis, proposisi, dan kesimpulan) dan aspek proses (dalam mendefinisikan penalaran dengan kata kerja tindakan, yaitu menyimpulkan). Analisis tersebut berpedoman pada prinsip-prinsip kognitif (Sfard, 2012) yang mengarah pada pencarian elemen diskursif dalam literatur, tetapi juga mempertimbangkan konteks dan kedudukan epistemologis di balik literatur.

Ketiga, informasi ini kemudian disintesis untuk menyoroti konvergensi, divergensi, dan untuk menunjukkan area di mana terdapat kesenjangan teoritis yang perlu diisi oleh model apa pun yang dapat mewakili aspek sentral penalaran. Dikarenakan tujuannya adalah untuk memberikan potret aspek sentral dari penalaran matematika, maka peneliti menghentikan proses ketika tidak ada informasi baru yang muncul. Setiap elemen yang muncul baik secara eksplisit maupun implisit terkait dengan penalaran matematika mengharuskan, peneliti merumuskan kembali dengan kata-kata yang mencerminkan pendekatan diskursif untuk penalaran matematika. Dari perspektif ini, konsep teoritis penalaran matematika yang dihasilkan dirancang untuk memungkinkan pemahaman penalaran matematika yang lebih baik dan lebih lengkap dalam konteks matematika disetiap jenjang pendidikan, serta alat untuk meningkatkan komunikasi. Selain itu, konsep ini bertujuan untuk menumbuhkan 
refleksi tentang penalaran matematika di antara para peneliti dan guru, mereka yang dengan tindakannya, dapat mempengaruhi pembelajaran siswa secara langsung atau tidak langsung. Wacana menjadi andalan guru untuk menilai apakah penalaran matematika terjadi di kelas. Berikut ini bagan alur review jurnal.

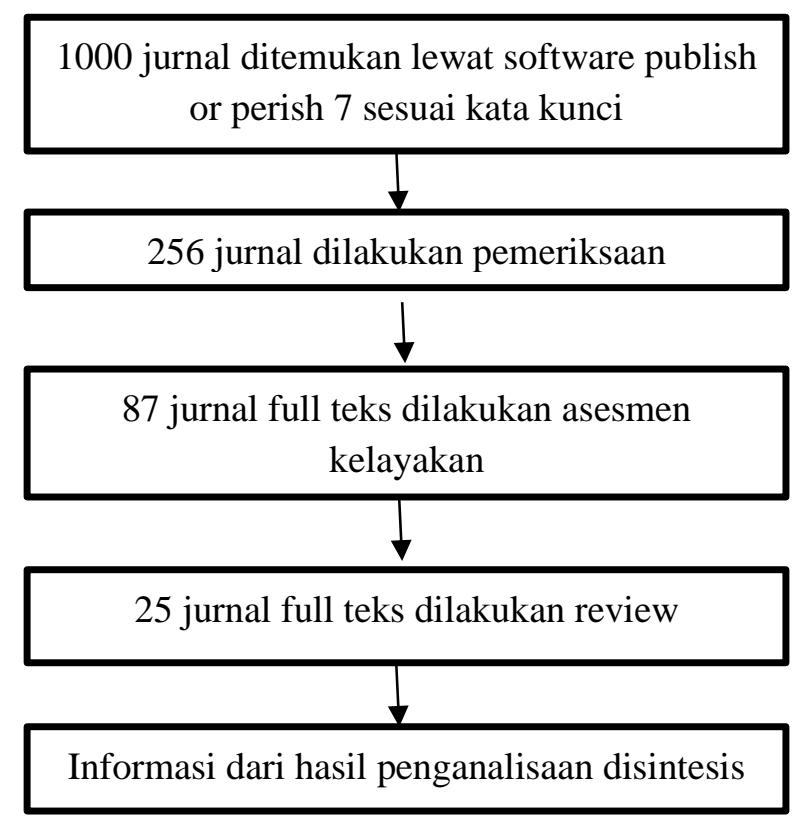

Gambar 1. Bagan Alur Review Jurnal

\section{HASIL DAN DISKUSI}

Empat elemen utama muncul dari analisis literatur pendidikan matematika, yang membantu untuk memperjelas kekaburan konseptual penalaran matematika adalah: dikotomi aktivitas/produk, sifat inferensial penalaran matematika, tujuan dan fungsi penalaran matematika, dan apa yang kita maksud sebagai aspek struktural dan proses. Dikotomi aktivitas/produk berkaitan dengan aktivitas penalaran yang dianggap tidak dapat diakses dan produk tersebut hanyalah petunjuk yang tidak sempurna (Stylianides, 2008). Sifat inferensial penalaran matematika ditekankan oleh banyak penulis yang menunjuk pada ide-ide baru yang dihasilkan dari suatu aktivitas penarikkan kesimpulan. Namun, sifat sebenarnya dari kebaruan ini masih harus diklarifikasi. Unsur tujuan dan fungsi penalaran juga menimbulkan pertanyaan, seperti apakah tujuan penalaran terbatas pada pembuktian? (De Villiers, 1999) atau apakah fungsi dari semua proses penalaran matematika adalah untuk mengubah nilai epistemik sebuah naratif (Duval, 1995). Akhirnya, penalaran matematika secara tradisional didefinisikan dalam istilah struktur, yaitu bentuk dimana alasan itu diungkapkan, apakah itu deduktif, induktif atau abduktif. Disisi lain, perspektif proses yang dianut oleh pihak lain cenderung tidak didefinisikan atau dieksplorasi secara epistemologi.

Artikulasi keempat elemen ini, digabungkan dalam perspektif kognitif yang mengarah pada definisi penalaran matematika sebagai proses komunikasi dengan orang lain atau dengan diri sendiri yang memungkinkan untuk menyimpulkan pernyataan matematika dari pernyataan matematika lainnya. 
Jadi elemen utama kedua ditangkap dalam definisi ini, yaitu sifat inferensial penalaran matematika yaitu elemen yang akan terlihat memainkan peran kunci, baik dalam aspek struktural dan proses penalaran matematika. Selain itu, dari analisis literatur dapat dikatakan bahwa penalaran matematika mengembangkan wacana dengan ekstensi (ekspansi diskursif endogen, dalam terminologi Sfard, 2008), yaitu tidak ada perubahan dalam aturan meta-diskursif; tidak ada objek matematika baru dalam pengertian kognitif. Kebaruan terletak di dalam ucapan tingkat objek itu sendiri. Definisi ini juga memungkinkan kita untuk menghindari unsur pertama, yaitu dikotomi aktivitas /produk, di mana wacana dalam kerangka dipandang sebagai aktivitas dan produk. Setiap tindakan komunikasi menghadirkan aspek aktivitas dan produk, yang diperoleh masing-masing dari proses dan aspek struktural penalaran matematika.

Seperti yang akan terlihat, aspek ganda yang terkait dengan elemen struktural dan proses memungkinkan untuk menyempurnakan definisi dan mengintegrasikan berbagai fungsi (elemen ketiga) penalaran matematika. Dengan demikian, elemen struktural dan proses, dalam hubungannya dengan aktivitas diskursif dari kerangka kerja kognitif yang mendasarinya, akan terlihat untuk menangkap keempat elemen penalaran matematika yang muncul dari literatur. Kedua aspek ini dielaborasi pada bagian berikutnya, dengan sedikit ruang yang dikhususkan untuk struktural karena telah dieksplorasi secara relatif baik dari perspektif epistemologis dalam literatur pendidikan matematika. Penting untuk ditekankan bahwa aspek struktural dan proses penalaran matematika mewakili dua cara berbeda dalam memandang wacana tertentu. Kedua aspek tersebut hadir dan terkait secara dialektis: struktur adalah bagian dari aspek proses penalaran matematika dan proses berkontribusi pada konstruksi struktur tersebut.

\section{Aspek Struktural Dari Penalaran Matematis}

Aspek struktural penalaran matematika secara umum mengacu pada aspek yang lebih statis yang terkait dengan bentuk penalaran matematika yang diberikan. Lebih khusus lagi, aspek struktural mengacu pada cara elemen-elemen diskursif bergabung dalam sebuah sistem yang teratur yang menggambarkan elemen-elemen tersebut dan hubungannya satu sama lain. Bentuk yang lebih banyak dikutip adalah deduksi, induksi, dan abduktif. Artikel Toulmin (2003) dan Peirce (2016) merupakan referensi yang lebih banyak digunakan untuk membahas aspek struktural dalam literatur. Model Toulmin menyusun skema elemen dasar (data, klaim, jaminan) bersama dengan kualifikasi (terkait dengan nilai epistemik), dukungan (untuk lebih mendukung jaminan), dan sanggahan (untuk mendahului kemungkinan argumen kontra untuk klaim tersebut). Semua elemen itu bersifat naratif dan berfungsi untuk menyusun wacana matematika. Model Peirce melibatkan tiga model dasar, yaitu model inferensi: deduktif, induktif, dan abduktif. Setiap langkah terdiri minimal dari data, klaim, dan jaminan (untuk menggunakan terminologi yang sama di kedua model). Deduktif, induktif, dan abduktif masingmasing menyimpulkan kesimpulan yang berbeda.

\section{Langkah Deduktif}


Bagi beberapa penulis penalaran deduktif identik dengan penalaran matematika. Duval (1995), menjelaskan penalaran deduktif sebagai satu-satunya bentuk penalaran yang dapat mengubah nilai epistemik pengetahuan matematika dari sesuatu yang mungkin menjadi benar. Sebagai aspek struktural, langkah deduktif menyimpulkan klaim dari data dan jaminan. Sifat kualifikasi yang dilampirkan pada klaim (yang merupakan kesimpulan untuk langkah deduktif) bergantung pada nilai epistemik data dan jaminan. Bentuk penalaran deduktif memainkan peran penting dalam proses pembuktian dan pembuktian formal, yang keduanya memerlukan restrukturisasi deduktif (lihat Bagian 2.b).

\section{Langkah Induktif}

Penalaran induktif adalah langkah paling umum kedua dalam literatur yang terkait dengan penalaran matematika. Ini didefinisikan secara tidak konsisten, karena mengacu pada setiap alasan yang tidak deduktif (Reid \& Knipping, 2010). Dalam artikel ini, langkah induktif menyimpulkan jaminan dari data dan klaim tentang data. Nilai epistemik yang diperbolehkan sehubungan dengan kesimpulan dari langkah induktif adalah terkait probabilitas/kemungkinan. Penalaran induktif dengan proses generalisasi yang akan segera dijelaskan (Rivera, 2008) di mana proses ini dapat menjadi terstruktur secara induktif.

\section{Langkah Abduktif}

Peneliti yang tertarik dengan studi tentang aktivitas eksplorasi, seperti Reid (2003), memperkenalkan langkah abduktif. Ini adalah struktur yang kurang dibahas serta terkadang bercampur dengan langkah induktif (Rivera, 2008). Menurut Eco (Reid, 2003), langkah abduktif dapat terjadi dalam dua bentuk. Yang pertama menyimpulkan data dari klaim dan jaminan. Yang kedua menyimpulkan data dan jaminan dari klaim. Untuk Peirce (2016), langkah abduktif menyimpulkan elemen-elemen yang dapat menjelaskan klaim tersebut. Struktur penalaran abduktif dapat menjadi elemen dari setiap proses penalaran matematika dengan menghasilkan data dan jaminan dalam pencarian persamaan dan perbedaan seperti dalam generalisasi, dugaan, dan juga memvalidasi (Pedemonte \& Reid, 2011).

\section{Kesimpulan Pada Aspek Struktural Penalaran Matematika}

Dari sudut pandang kognitif, aspek struktural merupakan aturan konstruksi wacana matematika serta komponennya yang beragam. Ini gambaran dari sifat pengambilan kesimpulan dan nilai epistemiknya. Menurut Peirce (2016), validitas penalaran tidak hanya dinilai dari strukturnya, tetapi dari nilai epistemik yang melekat pada kesimpulan, sehingga memberikan status khusus pada langkah deduktif. Hal ini berlawanan dengan definisi standar validitas logis di mana argumen valid jika dan hanya jika mengambil bentuk yang membuat premis tidak mungkin menjadi benar dan kesimpulannya tetap salah; tidak diperlukan validitas Argumen yang memiliki premis benar. Meta-aturan yang mengontrol wacana matematika (dalam komunitas matematika) menuntut wacana penalaran akhirnya terstruktur ke dalam langkah deduktif. Ini adalah struktur unik yang memungkinkan berteori dalam wacana matematika. 
Sekalipun diperlukan konsep penalaran matematika untuk pembelajaran matematika, namun aspek struktural belum cukup untuk sepenuhnya memahami sifat penalaran matematika. Meskipun mengedepankan, secara statis elemen naratif, relasi, dan nilai epistemik yang membentuk penalaran matematika, ia mengabaikan sifat temporalitas dan aksiologis penalaran matematis yang merupakan pusat aktivitas penalaran. Oleh karena itu, aspek proses akan mengisi celah tersebut.

\section{Aspek Proses Penalaran Matematis}

Beberapa kata kerja yang terkait dengan penalaran matematika dalam literatur merupakan kata kerja yang mengedepankan sifat temporal penalaran matematika. Namun, hanya sedikit artikel yang menjelaskan penalaran matematika sebagai suatu proses. Dari perspektif kognitif yang diadopsi di sini, definisi aspek proses penalaran matematika sebagai berikut: "Proses penalaran matematika adalah proses kognitif yang bersifat meta-diskursif, yaitu memperoleh narasi tentang objek atau hubungan dengan menjelajahi hubungan antar objek."

Dari beberapa proses penalaran matematika yang tumpang tindih yang ditemukan dalam literatur, ditemukan terdapat sembilan proses yang berbeda-beda. Delapan di antaranya diklasifikasikan ke dalam salah satu dari dua kategori: proses yang terkait dengan pencarian persamaan dan perbedaan, atau proses yang terkait dengan validasi. Kategori ini, yang mirip dengan yang dijelaskan oleh Stylianides (2008), setelah beberapa siklus umpan balik.

\section{Proses yang Berhubungan dengan Pencarian Persamaan dan Perbedaan}

Lima proses berhubungan dengan pencarian persamaan dan perbedaan adalah generalisasi, konjektur, mengidentifikasi pola, membandingkan, dan mengklasifikasi.

- Generalisasi. Menurut Stylianides (2008), penalaran matematika adalah tentang generalisasi dan sampai pada kesimpulan yang valid. Ia juga berpendapat generalisasi merupakan transportasi relasi matematika dari himpunan yang diberikan ke himpunan baru yang himpunan aslinya adalah himpunan bagian. Lebih lanjut Stylianides menyatakan, proses argumentasi yang melibatkan generalisasi memungkinkan untuk diteruskan ke himpunan yang lebih besar dan juga memberikan alasan untuk mempercayai narasi: argumentasi matematis selalu memiliki tujuan untuk mencari kebenaran. Aspek inferensial dan perluasan dari generalisasi dianggap fitur utamanya, sehingga mengarah ke definisi generalisasi berikut: "Generalisasi adalah sebuah proses yang menyimpulkan narasi tentang sekumpulan objek matematika."

Dari sudut pandang kognitif, kita dapat menghubungkan generalisasi dengan penalaran matematika karena prosesnya jelas terkait dengan inferensi dan wacana, tanpa harus menciptakan wacana baru yang tidak dapat dibandingkan. Sebaliknya, abstraksi (Jeannotte \& Kieran, 2017) menghasilkan pengembangan wacana meta-level dan karenanya tidak dianggap sebagai proses penalaran matematika dari perspektif kognitif.

- Konjektur. Menurut (Stylianides, 2008), spekulasi harus mengarah pada konjektur yang beralasan. Konjektur/Dugaan tersebut sebagai naratif yang kemudian dikaitkan dengan nilai epistemik, mungkin atau memungkinkan. Proses penalaran matematika lainnya dengan demikian 
diperlukan untuk menentukan apakah dugaan tersebut benar atau salah. Stylianides juga mengatakan bahwa, spekulasi mengarah pada ucapan yang menggeneralisasi kasus yang dihasilkan, yaitu memperluas domain aplikasinya. Mason et al (2010) mendeskripsikan dugaan sebagai proses siklus yang melibatkan: i) mengucapkan dengan jelas sebuah dugaan, ii) memverifikasi bahwa dugaan tersebut mencakup semua kasus dan contoh yang diketahui, iii) waspada terhadap dugaan dengan mencoba membantahnya, dan iv) mencari tahu mengapa itu benar atau memodifikasinya (yang membawa kita kembali ke i). Elemen terkait yang ditarik dari literatur adalah hubungan antara konjektur dan teorema. Stylianides (2008) menyatakan bahwa argumentasi terkait dengan konjektur dan pembuktian formal dikaitkan dengan teorema.

Dengan demikian, beberapa elemen dipertahankan untuk membangun definisi dugaan sebagai proses penalaran matematika. Pertama, elemen sentral adalah pencarian keteraturan dan pencarian beberapa relasi. Faktanya, pencarian persamaan dan perbedaanlah yang muncul dari analisis. Pencarian ini memungkinkan untuk membangun relasi di sekitar objek atau relasi lain yaitu di sekitar fenomena matematika. Kedua, dugaan yang mengarah pada narasi dengan kemungkinan atau kemungkinan besar sebagai nilai epistemiknya. Di mana ada ketidakpastian tentang narasi yang dibangun. Ketiga, berspekulasi dapat mengarah pada wacana umum ketika memperluas hubungan yang diamati ke himpunan yang lebih besar. Yang membedakan dugaan dari generalisasi adalah bahwa ia memiliki nilai epistemik yang melekat padanya. Dengan demikian, dugaan dapat didefinisikan sebagai berikut: "Dugaan adalah proses penalaran matematika dengan mencari persamaan dan perbedaan, menyimpulkan narasi tentang beberapa keteraturan dengan nilai epistemik yang mungkin dan yang memiliki potensi untuk teori matematika". Dari sudut pandang kognitif, menduga mengarah pada perluasan wacana dengan membangun narasi yang mungkin, berdasarkan pencarian persamaan dan perbedaan.

- Mengidentifikasi pola. Apakah mengidentifikasi pola berbeda dari proses dugaan? Misalnya, apakah ada kemungkinan nilai epistemik melekat pada pengidentifikasian pola? Menurut Stylianides (2008), mengidentifikasi pola dapat mengarah pada dugaan, tetapi keduanya tidak dapat disamakan. Untuk Cañadas et al (2007), tahap ketiga dari dugaan (yaitu, induksi empiris dari sejumlah kasus diskrit yang terbatas) adalah pencarian dan prediksi keteraturan dalam pola, yang jelas terkait dengan mengidentifikasi pola. Mengidentifikasi pola, menurut Stylianides (2008), lebih dari sekadar mengamati pola. Ada pencarian aktif, dan kemudian mengambil jarak dari fenomena tersebut, yang diperlukan untuk penalaran matematika. Selanjutnya, untuk generalisasi tidak ada nilai epistemik tertentu yang terkait dengan narasi yang disimpulkan. Dengan demikian dapat disimpulkan mengidentifikasi pola sebagai berikut: "Mengidentifikasi pola adalah Proses penalaran matematika yang dengan mencari persamaan dan perbedaan, menyimpulkan narasi tentang hubungan rekursif antara objek atau hubungan matematika". Dari sudut pandang kognitif, mengidentifikasi pola berbeda dari dugaan dan generalisasi karena 
dimungkinkan untuk mengidentifikasi pola yang dapat diterapkan pada himpunan tertentu tanpa mengembangkannya ke himpunan yang lebih besar.

- Membandingkan. Istilah membandingkan dihubungkan oleh berbagai peneliti dengan elemen tertentu dari penalaran matematika, seperti penalaran induktif (Simon, 1996) dan penalaran deduktif (Duval, 1995). Stylianides (2008) menghubungkan membandingkan dengan contoh dan dugaan. Baginya, penalaran matematika pada suatu saat harus melibatkan perbandingan contohcontoh agar bisa berspekulasi. Elemen kunci di sini adalah sifat inferensial dari perbandingan, yang didefinisikan sebagai berikut: "Membandingkan adalah proses penalaran matematika yang menyimpulkan, dengan mencari persamaan dan perbedaan, narasi tentang objek atau hubungan matematika". Pembandingan dapat terjadi bersamaan dengan kebanyakan proses penalaran matematika lainnya: menggeneralisasi, mengidentifikasi pola, memvalidasi. Misalnya, mengidentifikasi pola memerlukan perbandingan kasus atau contoh untuk menyoroti pola tersebut. Namun, mengidentifikasi pola lebih dari sekadar membandingkan karena membandingkan hanya menyimpulkan narasi tentang persamaan dan perbedaan.

- Klasifikasi. Klasifikasi dikaitkan dengan penalaran matematika. Menurut Mason (2001), klasifikasi tidak hanya tentang membuat perbedaan dan mendeskripsikan sifat, tetapi tentang membenarkan dugaan bahwa semua objek yang mungkin dengan sifat tersebut telah dijelaskan atau diterima. Mason (2001) menyoroti aturan meta-diskursif di mana pengklasifikasian bergantung: sifat dan definisi matematika yang digunakan untuk mengklasifikasikan objek. Proses pengklasifikasian didefinisikan sebagai berikut: Klasifikasi adalah proses penalaran matematika yang menyimpulkan, dengan pencarian persamaan dan perbedaan antara objek matematika, sebuah narasi tentang kelas objek berdasarkan sifat dan definisi matematika. Pengklasifikasian adalah proses penting yang memungkinkan pengembangan level objek dengan menyatukan atau memisahkan objek diskursif yang berbeda, sehingga menata wacana. Pengelompokan dapat dikaitkan dengan membandingkan, menduga, dan menggeneralisasi.

\section{Proses yang terkait dengan validasi}

Untuk rangkaian proses kedua, digambarkan oleh Duval (1995), Lithner (2006), dan Cañadas et al (2007), istilah validasi terkait dengan nilai epistemik yang dapat diambil dalam narasi tertentu (misalnya, mungkin benar, mungkin salah) dan bergantung pada komunitas wacana matematika di mana ia muncul. Tidak seperti Duval (1995), dari sudut pandang diskursif tidak ada perbedaan antara nilai epistemik dan nilai kebenaran. Nilai epistemik suatu ucapan tidak hanya bergantung pada validitas logis dari strukturnya tetapi juga pada wacana bersama (aturan dan narasi yang diterima) dari komunitas tertentu. Nilai epistemik ini, dipandang sebagai salah satu aspek struktural, yang mana sangat penting dalam matematika untuk diskursus sistematis dan berteori. Tiga proses di bawah ini, yang terkait dengan validasi, didefinisikan secara inklusif sebagai berikut "Validasi adalah Proses penalaran matematika 
yang bertujuan untuk mengubah nilai epistemik (yaitu, kemungkinan atau kebenaran) dari narasi matematika".

Berlawanan dengan dugaan yang menyimpulkan narasi yang mungkin terjadi, proses validasi bertujuan untuk mengubah nilai epistemik naratif dengan satu atau lebih cara. Perubahan ini bisa dari kemungkinan salah menjadi benar, dari kemungkinan benar menjadi salah, atau bahkan dari cenderung menjadi lebih mungkin. Aturan meta-diskursif matematika membatasi kemungkinan perubahan nilai epistemik. Sebagian dari definisi validasi inilah yang akan membantu kita menyoroti perbedaan kekhususan dari tiga proses terkait validasi yang muncul dari analisis literatur: membenarkan, membuktikan, dan membuktikan secara formal. Untuk ketiga definisi tersebut, kata mencari telah dimasukkan untuk menekankan sifat proses dari aktivitas. Ini melibatkan pencarian informasi diskursif (data, jaminan, dukungan), yang memungkinkan perubahan nilai epistemik.

- Justifying. Justifying/pembenarkan dipandang oleh Yackel \& Hanna (2003) sebagai proses sosial, yaitu lebih dari satu individu dapat terlibat dan proses tersebut didasarkan pada pengetahuan umum. Demikian pula, Duval (1995) dan Stylianides (2008) berpendapat proses ini terkait dengan perubahan nilai epistemik sebuah narasi dengan mencari data, jaminan, atau dukungan untuk mendukung perubahan ini. Namun, dalam literatur yang dibahas adalah bagian dari kemungkinan menjadi benar. Namun demikian, proses pembenaran dikaitkan dengan dua jenis bagian epistemik. Yang pertama terkait dengan pembenaran sebuah dugaan yang muncul dari proses dugaan. Bagian ini memungkinkan untuk mengubah nilai epistemik dari kemungkinan menjadi lebih mungkin, seperti yang ditekankan oleh Duval (1995) dalam pembahasannya tentang validasi yang masuk akal. Jenis kedua dari bagian epistemik terkait dengan validasi yang mengubah nilai epistemik dari kemungkinan menjadi benar atau salah, tanpa dianggap sebagai proses pembuktian. Jadi, pembenaran didefinisikan sebagai berikut: "Pembenaran adalah proses penalaran matematika dengan mencari data, jaminan, dan dukungan, yang memungkinkan untuk mengubah nilai epistemik sebuah naratif".

Perubahan nilai epistemik, seperti yang baru saja disebutkan, belum tentu dari kemungkinan menjadi benar. Unsur-unsur yang mendukung proses tersebut dibatasi oleh aturan-aturan metadiskursif dalam komunitas tertentu. Misalnya, perubahan dari cenderung menjadi benar harus didasarkan pada struktur deduktif. Di sisi lain, dalam mengubah dari cenderung menjadi lebih mungkin, beberapa meta-aturan membatasi proses, tetapi struktur deduktif tidak diperlukan.

- Proving. Literatur tentang proving/pembuktian dapat dibagi menjadi dua kelompok: artikel yang membahas pembuktian dan artikel yang membahas tentang pembuktian formal. Bagian selanjutnya membahas pembuktian formal. Pembuktian didefiniskan seperti kasus pembenaran yaitu proses sosial. Menurut Stylianides (2008), pembuktian merupakan jenis penjelasan yang dapat diterima secara umum. Selain itu, pembuktian terkait dengan perubahan nilai epistemik sebuah naratif: pembuktian adalah proses yang digunakan oleh individu (atau komunitas) untuk menghilangkan keraguan tentang kebenaran suatu pernyataan (Harel \& Sowder, 2007). Namun, 
proses pembuktian lebih dikaitkan dengan penalaran deduktif daripada proses pembenaran. Untuk Maher (2009), pembuktian adalah jenis khusus dari aktivitas matematika di mana anakanak berusaha untuk membenarkan klaim mereka dengan argumentasi deduktif. Jadi, dapat disimpulkan proses pembuktian sebagai berikut: "Pembuktian adalah proses penalaran matematika dengan mencari data, jaminan, dan dukungan, mengubah nilai epistemik sebuah narasi dari kemungkinan menjadi benar".

Menurut Sfard (2008), proses ini dibatasi oleh:

- Narasi yang diterima oleh komunitas kelas yang benar (dari sudut pandang ahli matematika) dan tersedia tanpa justifikasi tambahan;

- Restrukturisasi akhir yang bersifat deduktif;

- Realisasi yang sesuai dan diketahui atau dapat diakses oleh kelas

Dalam matematika, struktur deduktif dikaitkan dengan ketelitian. Sementara aturan metadiskursif wacana matematika menyatakan bahwa proses validasi harus direstrukturisasi dengan cara deduktif di beberapa titik, dapat ditekankan bahwa membuktikan sebagai suatu proses yang tidak harus terstruktur setiap saat. Gagasan teori yang digarisbawahi oleh Mariotti (2006) adalah bahwa pembuktian bergantung pada sekumpulan narasi yang diterima sebagai benar. Selain itu, dengan menerima realisasi nonformal, proses pembuktian dapat dikembangkan dari sekolah dasar dan seterusnya. Pembuktian dibedakan dari pembenaran dalam potensinya untuk berteori. Hal ini juga lebih dibatasi dibandingkan pembenarkan, karena itu harus direstrukturisasi secara deduktif dan didasarkan pada serangkaian narasi yang diterima, yang koheren dengan wacana ahli matematika, sekalipun jika direalisasikan secara berbeda (informal).

- Pembuktian formal. Menurut Hanna \& Jahnke (1996), bukti formal muncul sebagai tanggapan atas perhatian yang berkelanjutan untuk pembenaran di antara para ahli matematika. Pembuktian formal sangat terkait dengan perubahan nilai epistemik. Untuk Stylianides (2008), pembuktian formal dibatasi oleh struktur dan meta-aturan yang ketat. Arsac (1996) menyoroti sifat sosial dari meta-aturan tersebut dengan teori yang dibawa ke latar depan. Pembuktian formal dapat dibedakan dari pembuktian biasa melalui ketelitian dan formalismenya. Sementara proses pembuktian didasarkan pada narasi yang benar secara matematis, proses pembuktian formal berjalan lebih jauh di mana narasi harus diintegrasikan secara eksplisit ke dalam beberapa teori matematika. Pembuktian formal dengan demikian didefinisikan sebagai berikut: "Pembuktian formal adalah Proses penalaran matematika dengan mencari data, jaminan, dan dukungan, mengubah nilai epistemik sebuah narasi dari kemungkinan menjadi benar".

Menurut Sfard (2008), proses ini dibatasi oleh:

- Narasi yang diterima oleh komunitas kelas yang benar (dari sudut pandang ahli matematika) dan disistematisasi dalam teori matematika.

- Restrukturisasi deduktif akhir. 
- Realisasi yang diformalkan dan diterima oleh kelas dan komunitas matematika.

Berbeda dengan pembuktian, pembuktian formal bergantung pada teori matematika yang dibangun secara apriori dan pada realisasi formal (aksioma dan teorema). Akibatnya, contoh umum seperti yang dielaborasi oleh Stylianides (2008), dapat diterima dalam proses pembuktian yang dijelaskan sebelumnya, tetapi tidak dapat digunakan dalam pembuktian formal.

\section{Kesimpulan pada aspek proses penalaran matematika}

Sekalipun telah diperlakukan secara terpisah, semua proses penalaran matematika saling berkaitan. Mereka menstimulus dan mempengaruhi satu sama lain, dan memungkinkan untuk pengembangan wacana matematika yang semakin kompleks dengan generasi narasi baru pada objek diskursif yang sudah ada. Secara khusus, dugaan dan pembuktian memainkan peran penting dalam teori matematika. Memang, dugaan menyimpulkan narasi yang berpotensi memperkaya teori matematika dan membuktikan kemungkinkan untuk mensistematisasikan wacana, dengan gagasan berteori. Bahkan jika matematika sekolah tidak diformalkan dengan cara yang sama seperti matematika para matematikawan (sistematisasi wacana) dan agak lokal, namun tetap dapat melibatkan proses dugaan dan pembuktian. Terlihat juga misalnya, bagaimana keteladanan terkait erat baik dengan proses yang terkait dengan pencarian persamaan dan perbedaan dan dengan proses yang terkait dengan validasi.

\section{KESIMPULAN}

Dua aspek utama untuk menangkap karakteristik sentral dari penalaran matematika adalah aspek struktural dan aspek proses. Aspek struktural dalam penalaran matematika secara umum mengacu pada aspek yang lebih statis yang terkait dengan bentuk penalaran matematika yang diberikan. Lebih khusus lagi, aspek struktural mengacu pada cara elemen-elemen diskursif bergabung dalam sebuah sistem yang teratur yang menggambarkan elemen-elemen tersebut dan hubungannya satu sama lain. Aspek struktural penalaran matematika adalah deduksi, induksi dan abduktif. Sedangkan, aspek proses penalaran matematika adalah proses kognitif yang bersifat meta-diskrufsif, yaitu memperoleh narasi tentang objek atau hubungan dengan menjelajahi antar objek. Dari beberapa proses penalaran matematika yang tumpang tindih yang ditemukan dalam literatur, sembilan proses berbeda muncul. Delapan di antaranya diklasifikasikan ke dalam salah satu dari dua kategori: proses yang terkait dengan pencarian persamaan dan perbedaan, atau proses yang terkait dengan validasi.

\section{UCAPAN TERIMA KASIH}

Diucapkan terima kasih kepada semua pihak yang telah membantu pelaksanaan penelitian ini terutama kepada dosen pembimbing yang telah memberikan saran dan tambahan dalam penulisan artikel ini. 


\section{REFERENSI}

Arsac, G. (1996). Un cadre d'étude du raisonnement mathématique. Grenoble: IMAG.

Bernard, M., \& Chotimah, S. (2018). Improve student mathematical reasoning ability with open-ended approach using VBA for powerpoint. AIP Conference Proceedings, 2014(September).

Cañadas, M. C., Deulofeu, J., Figueiras, L., Reid, D., \& Yevdokimov, O. (2007). The Conjecturing Process: Perspectives in Theory and Implications in Practice. Journal of Teaching and Learning, $5(1)$.

Creswell, J. W. (2003). Research Design: Qualitative, Quantitative, and Mixed methods approaches. In Sage Publication.

De Villiers, M. (1999). The role and function of proof with Sketchpad. Rethinking Proof with the Geometer's Sketchpad, 24, 17-24. http://academic.sun.ac.za/education/mathematics/MALATI/Files/proof.pdf

Duval, R. (1995). Sémiosis et pensée humaine: registres sémiotiques et apprentissages intellectuels. In Berne: Peter Lang.

Grouws, D. A. (2006). Handbook of research on mathematics teaching and learning: A Project of the National Council of Teacher of Mathematics. Mathematics Teaching, 6179(619), 1-60.

Hanna, G., \& Jahnke, H. N. (1996). Chapter 23 : Proof and Proving. Journal for Research in Mathematics Education, 22, 390-408.

Harel, G. Sowder, L. (2007). Toward comprehensive perspectives on the learning and teaching of proof. Second handbook of research on mathematics teaching and learning, 2, 805-842

Jeannotte, D., \& Kieran, C. (2017). A conceptual model of mathematical reasoning for school mathematics. Educational Studies in Mathematics, 96(1), 1-16.

Lithner, J. (2006). A framework for analysing creative and imitative mathematical reasoning. Educational Studies in Mathematics, 67, 255-276.

Maher, C. A. (2009). Children's reasoning: Discovering the idea of mathematical proof. In Teaching and Learning Proof Across the Grades: A K-16 Perspective (pp. 120-132). New York: Routledge.

Mariotti, M. A. (2006). Proof and proving in mathematics education. In Handbook of research on the psychology of mathematics education (pp. 173-204). Brill Sense

Mason, J, Burton, L., \& Stacey, K. (2010). Thinking Mathematically Second Edition. Pearson Higher Ed.

Mason, John. (2001). Questions about Mathematical Reasoning and proof in Schools ( Opening Address To QCA Conference Oct 2001 ). Opening Address To QCA Conference UK, 1685, 1-11.

Meyer, M. (2010). Abduction-A logical view for investigating and initiating processes of discovering mathematical coherences. Educational Studies in Mathematics, 74(2), 185-205.

NCTM. (2000). Principles and standards for school mathematics. Reston,VA: NCTM, 1-22. 
OCDE. (2006). Compétences en sciences, lecture et mathématiques. Le Cadre d'évaluation de PISA 2006. Paris: OCDE.

Pedemonte, B., \& Reid, D. (2011). The role of abduction in proving processes. Educational Studies in Mathematics, 76(3), 281-303.

Peirce, C. S. (2016). Prolegomena to a science of reasoning: Phaneroscopy, semeiotic, logic.. Peter Lang.

Reid, D.A, Knipping, C. (2010). Proof in Mathematics Education. Research, Learning and Teaching. Sense Publishers, Rotterdam/Boston/Taipei, 10, 179-192.

Reid, D. A. (2003). Forms and uses of abduction. Proceedings of the 3th Conference of the European Society in Mathematics Education, 1-10.

Rivera, F. D. (2008). On the Pitfalls of Abduction: Compolicities and Complexities in Patterning Activity. For the Learning of Mathematics, 28(1), 17-25.

Sfard, A. (2012). Introduction: Developing mathematical discourse-Some insights from communicational research. International Journal of Educational Research, 51-52, 1-9.

Sfard, A. (2008). Thinking as communicating: Human development, the growth of discourses, and mathematizing. Cambridge University Press

Simon, M. A. (1996). Beyond inductive and deductive reasoning: The search for a sense of knowing. Educational Studies in mathematics, 30(2), 197-210.

Stylianides, G. J. (2008). An Analytic Framework Of Reasoning-And-Proving. For the Learning of Mathematics, 28(1), 9-16. Retrieved December 9, 2020, from http://www.jstor.org/stable/40248592

Shuttleworth, M (Sep 16, 2009). What is a Literature Review?. Retrieved Des 04, 2020 from Explorable.com: https://explorable.com/what-is-a-literature-review

Toulmin, S. E. (2003). The uses of argument (Updated edition, first published in 1958). Cambridge University Press.

Van der Maren, J.-M. (1996). Méthodes de recherche pour l'éducation. Méthodes En Sciences Humaines, 502.

Yackel, E., \& Hanna, G. (2003). Reasoning and proof. A Research Companion to Principles and Standards for School Mathematics, 227-236. 